\title{
RESEARCH
}

Open Access

\section{Aß40 displays amyloidogenic properties in the non-transgenic mouse brain but does not exacerbate Aß42 toxicity in Drosophila}

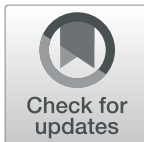

Lorena De Mena ${ }^{1,2,3}$, Michael A. Smith2,3, Jason Martin ${ }^{2,3}$, Katie L. Dunton ${ }^{2,3}$, Carolina Ceballos-Diaz ${ }^{2,3}$, Karen R. Jansen-West ${ }^{4}$, Pedro E. Cruz ${ }^{2,3}$, Kristy D. Dillon ${ }^{2,3}$, Diego E. Rincon-Limas ${ }^{1,2,3}$, Todd E. Golde ${ }^{2,3}$, Brenda D. Moore $2,3^{*}$ and Yona Levites ${ }^{2,3^{*}}$ (D)

\begin{abstract}
Background: Self-assembly of the amyloid- $\beta(A \beta)$ peptide into aggregates, from small oligomers to amyloid fibrils, is fundamentally linked with Alzheimer's disease (AD). However, it is clear that not all forms of $A \beta$ are equally harmful and that linking a specific aggregate to toxicity also depends on the assays and model systems used (Haass et al., J Biol. Chem 269:17741-17748, 1994; Borchelt et al., Neuron 17:1005-1013, 1996). Though a central postulate of the amyloid cascade hypothesis, there remain many gaps in our understanding regarding the links between $A \beta$ deposition and neurodegeneration.
\end{abstract}

Methods: In this study, we examined familial mutations of A $\mathrm{B}$ that increase aggregation and oligomerization, E22G and $\Delta E 22$, and induce cerebral amyloid angiopathy, E22Q and D23N. We also investigated synthetic mutations that stabilize dimerization, S26C, and a phospho-mimetic, S8E, and non-phospho-mimetic, S8A. To that end, we utilized BRI2-A $\beta$ fusion technology and rAAV2/1-based somatic brain transgenesis in mice to selectively express individual mutant $A \beta$ species in vivo. In parallel, we generated PhiC31-based transgenic Drosophila melanogaster expressing wild-type (WT) and $A \beta 40$ and $A \beta 42$ mutants, fused to the Argos signal peptide to assess the extent of $A \beta 42-$ induced toxicity as well as to interrogate the combined effect of different $A \beta 40$ and $A \beta 42$ species.

Results: When expressed in the mouse brain for 6 months, AB42 E22G, AB42 E22Q/D23N, and AB42WT formed amyloid aggregates consisting of some diffuse material as well as cored plaques, whereas other mutants formed predominantly diffuse amyloid deposits. Moreover, while AB40WT showed no distinctive phenotype, AB40 E22G and $\mathrm{E} 22 \mathrm{Q} / \mathrm{D} 23 \mathrm{~N}$ formed unique aggregates that accumulated in mouse brains. This is the first evidence that mutant $A \beta 40$ overexpression leads to deposition under certain conditions. Interestingly, we found that mutant A 342 E22G, E22Q, and S26C, but not Aß40, were toxic to the eye of Drosophila. In contrast, flies expressing a copy of $A \beta 40$ (WT or mutants), in addition to $A \beta 42 W T$, showed improved phenotypes, suggesting possible protective qualities for $A \beta 40$.

\footnotetext{
* Correspondence: brendar@ufl.edu; levites.yona@ufl.edu

${ }^{2}$ Center for Translational Research in Neurodegenerative Disease and Department of Neuroscience, Gainesville, FL, USA

Full list of author information is available at the end of the article
}

(c) The Author(s). 2020 Open Access This article is licensed under a Creative Commons Attribution 4.0 International License, which permits use, sharing, adaptation, distribution and reproduction in any medium or format, as long as you give appropriate credit to the original author(s) and the source, provide a link to the Creative Commons licence, and indicate if changes were made. The images or other third party material in this article are included in the article's Creative Commons licence, unless indicated otherwise in a credit line to the material. If material is not included in the article's Creative Commons licence and your intended use is not permitted by statutory regulation or exceeds the permitted use, you will need to obtain permission directly from the copyright holder. To view a copy of this licence, visit http://creativecommons.org/licenses/by/4.0/. The Creative Commons Public Domain Dedication waiver (http://creativecommons.org/publicdomain/zero/1.0/) applies to the data made available in this article, unless otherwise stated in a credit line to the data. 
(Continued from previous page)

Conclusions: These studies suggest that while some $A \beta 40$ mutants form unique amyloid aggregates in mouse brains, they do not exacerbate Aß42 toxicity in Drosophila, which highlights the significance of using different systems for a better understanding of AD pathogenicity and more accurate screening for new potential therapies.

Keywords: Alzheimer's disease, Amyloid plaques, Cognitive impairment, Drosophila, Fruit fly

\section{Background}

The accumulation of misfolded proteins is a common feature of a number of neurodegenerative disorders including Alzheimer's disease $(\mathrm{AD})$. Multimerization of the amyloid- $\beta$ $(\mathrm{A} \beta)$ peptide is an early and central process in the development and progression of $\mathrm{AD}[1,2]$. $\mathrm{A} \beta$ is produced through the sequential cleavage of the amyloid precursor protein (APP) by $\beta$ - and $\gamma$-secretases [3, 4]. First, $\beta$-secretase cleaves APP into a soluble amino terminal ectodomain, APP $\beta$, and a 99-amino-acid C-terminal fragment- $\beta$ (CTF $\beta)[5,6]$. Then, $\gamma$-secretase cleaves CTF $\beta$ to generate APP intracellular domain (AICD) and releases $A \beta 48$ and $A \beta 49$. In the final step, $\gamma$-secretase trims $A \beta 48$ and $A \beta 49$ sequentially by three amino acid residues at a time, to produce $A \beta 42$ and $A \beta 40$, respectively [7]. Although the major species produced is $\mathrm{A} \beta 40, \mathrm{~A} \beta 42$ is much more amyloidogenic and is considered the toxic species despite being generated at lower levels $(\sim$ $5-10 \%$ of total $A \beta)$. It is currently unknown why $A \beta$, which is a naturally produced protein, begins to misfold and aggregate in the brain. While most instances of $A D$ are sporadic, $10-15 \%$ of $A D$ cases are due to familial mutations of $A \beta$ and result in extensive amyloid pathology within the brain and vasculature, called amyloidosis cerebral amyloid angiopathy (CAA) [3, 8]. Strong evidence suggests that the vast majority of these mutations are associated with earlier disease onset, faster amyloid aggregation, and more aggressive toxicity to the cells [9]. It is widely believed that amyloid aggregates in the brain can form diffuse as well as compact plaques. Nevertheless, the exact role of mutant $A \beta$ species in the underlying pathology has not been shown. The pathological phenotypes caused by mutations that alter amino acid residues within the $A \beta$ sequence are variable, and the underlying pathogenetic mechanisms are not fully understood $[10,11]$. In vitro studies have revealed that fibril formation of $A \beta$ is a complex process in which nucleation of assembly is the ratelimiting step $[12,13]$. Recent data support the notion that intra-A $\beta$ amino acid substitutions affect peptide selfassociation [14]. Several familial forms of $\mathrm{AD}$, characterized by single amino acid mutations at residues E22 or D23 of $\mathrm{A} \beta$, located in the turn of the $\beta$-hairpin, include the Italian (E22K), Arctic (E22G), Dutch (E22Q), and Iowa (D23N) familial mutants. $A \beta 40$ and $A \beta 42$ variants containing these mutations have faster folding nucleation and have been found to be more neurotoxic and to aggregate more readily than the wild-type (WT) peptide in in vitro experiments. $\mathrm{A} \beta 42 \mathrm{E} 22 \mathrm{Q}, \mathrm{D} 23 \mathrm{~N}$, and E22K mutations cause hereditary cerebral hemorrhage with amyloidosis, supporting the evidence that $A \beta$ mutants at positions 22 and 23 show increased neurotoxicity than wild-type $A \beta[15,16]$. The E22G mutation causes early-onset $\mathrm{AD}$ that involves enhanced protofibril formation [17]. Another familial mutation reported in recent years, termed Osaka $(\Delta \mathrm{E} 22)$, causes severe dementia, cerebellar ataxia, and gait disturbances in the absence of senile plaques [18]. It has been shown that deletion of E22 results in enhanced oligomerization of $A \beta[19]$.

To further understand $A \beta$ aggregation dynamics, previous studies have introduced mutations to stabilize $A \beta$ aggregates. It has been proposed, for example, that $A \beta$ dimer, designed by a cross-linked replacement of $\operatorname{Ser}^{26}$ with cysteine, rapidly forms toxic protofibrils [20, 21]. Additionally, it was postulated that phosphorylation of serine residue 8 promotes aggregation by stabilization of $\beta$-sheet conformation of $A \beta$ and increased formation of oligomeric $A \beta$ aggregates that represent nuclei for fibrillization [22].

A number of $\mathrm{AD}$ mouse models were developed in recent years, based on overexpression of transgenes containing Familial AD (FAD) mutations. Most of these models exhibited age-dependent amyloid deposition in the brain along with thioflavin-S-positive plaques, including compact plaques with dense cores that are reminiscent of those seen in human AD [23, 24]. Different promoters and genetic backgrounds prevent comparison of these models, and the fact that full-length APP is overexpressed can influence the respective development of behavioral and pathological features. Several years ago, new mouse models were developed based on genetic constructs that express fusion proteins between the BRI2 protein, involved in amyloid deposition in familial British dementia and $A \beta$. These mice express $A \beta$ peptides in the absence of APP. BRI2-A $\beta 40$ mice do not exhibit amyloid pathology, whereas BRI2-A $\beta 42$ mice accumulate detergent-insoluble $A \beta$ as they age [25].

Here, we used mouse models to investigate the potential pathogenic role of mutant $A \beta$ peptides in vivo. To do so, we used recombinant adeno-associated virus (rAAV) vectors to express A $\beta$ E22G, E22Q/D23N, $\Delta$ E22, S8E phospho-mimetic and S8A non-phospho-mimetic, and S26C dimer mutants using the BRI2 fusion strategy [26-28]. This approach allows individual delivery of $A \beta$ mutants to the mouse brain to compare their aggregation patterns $[28,29]$. Although mouse models are useful 
at examining amyloid pathology and glial involvement, they typically do not show significant AD relevant neurodegenerative changes $[30,31]$. Therefore, we then expressed A $340 / A \beta 42$ E22G, E22Q, and A 342 S26C in Drosophila to examine the neurotoxicity of the mutant A $\beta$ transgenes under similar expression levels. The questions our study is raising are as follows: Do $A \beta$ mutant aggregates in vivo display the characteristics of individual $A \beta$ strains? Does $A \beta$ that aggregates faster cause neuronal toxicity? Does $A \beta 40$ bearing an aggregationprone mutation accumulate in vivo and cause toxicity? Does the theory of "templating" the aggregation work when the seed is formed from individual $A \beta$ species and not from brain homogenate?

\section{Methods}

\section{Mice and neonatal injections}

B6C3H-F1 mice were obtained from Envigo. All animal procedures were performed with approval from the University of Florida Institutional Animal Care and Use Committee. All animals were housed three to five to a cage and maintained on ad libitum food and water with a 12-h light/dark cycle. Intracerebroventricular injections of rAAVs were carried out on day $\mathrm{P} 0$ as described previously [32]. Two microliters of rAAV2/1 encoding $A \beta 42$ WT, A 342 E22G, A 342 E22Q/D23N, A $342 \Delta$ E22, A $\beta 42$ S8A, A 342 S26C, A 440 WT, A $\beta 40$ E22G, or A 440 E22Q/D23N was administered bilaterally. At endpoint, mice were euthanized, brains were harvested, and one hemibrain was fixed overnight in $4 \%$ paraformaldehyde solution at $4{ }^{\circ} \mathrm{C}$ for immunohistochemical staining. Another hemibrain was flash frozen for biochemical fractionation and ELISA.

\section{A $\beta$ ELISA assay}

The frozen cortex was sequentially extracted with protease inhibitor cocktail (Roche) containing Tris-buffered saline, RIPA buffer, $2 \%$ SDS, and 70\% formic acid (FA) as described previously at a concentration of $150 \mathrm{mg} / \mathrm{ml}$ [32]. A $\beta$ levels in the $2 \%$ SDS-soluble and SDS-insoluble, $70 \%$ FA-soluble fractions were quantified using endspecific sandwich ELISA as previously described [33]. A $\beta 42$ was captured with mAb 2.1.3 (human A $335-42$ specific; T.E. Golde) and detected by HRP-conjugated mAb 33.1.1 (human A $\beta 1-16$; T.E. Golde). ELISA results were analyzed using SoftMax Pro software (Molecular Devices).

\section{Immunohistochemical imaging}

The right hemisphere of all injected mice was fixed in formalin, embedded in paraffin, sectioned, and stained with a biotinylated pan- $\mathrm{A} \beta$ antibody Ab5 (1:500, human A $\beta 1-16$ specific; T.E. Golde). Immunohistochemically stained sections were captured using the Scansope XT image scanner (Aperio; Leica Biosystems) or BX 60 (Olympus) and analyzed using the ImageScope program.

\section{Generation of transgenic flies expressing mutant $A \beta$ species}

To generate transgenic flies expressing comparable levels of $\mathrm{A} \beta$ transgene, all cDNA sequences (A $340 \mathrm{WT}, \mathrm{E} 22 \mathrm{G}$, $\mathrm{E} 22 \mathrm{Q}$, and S26C, as well as A $342 \mathrm{WT}, \mathrm{E} 22 \mathrm{G}, \mathrm{E} 22 \mathrm{Q}$, and S26C) were cloned under the UAS of the pJFRC-MHU vector, which carries an attB site for site-directed integration. All $A \beta$ peptides were fused to the Argos signal peptide to ensure secretion. The resulting constructs were microinjected into yellow white (yw) embryos at Rainbow Transgenics (Camarillo, CA) and targeted to the same genomic location, the attP2 site on chromosome 3, to achieve similar expression levels in vivo. The flies were raised and maintained at $25^{\circ} \mathrm{C}$ in regular media prior to experimentation. To express the $A \beta$ constructs, we combined these transgenic lines with the glass multimer reporter (GMR)-Gal4 driver (all eye cells). pJFRC-MUH was a gift from G. Rubin (plasmid \#26213; Addgene [34];).

\section{Drosophila eye imaging}

To generate the eye images, we crossed GMR-Gal4 or GMR-Gal4;A $\beta 40 / 42$ stocks with each mutant transgene at $25^{\circ} \mathrm{C}$. Two days after eclosion, we collected females from the progeny, serially dehydrated in ethanol, airdried in hexamethyldisilazane (Electron Microscope Sciences), and metal-coated for photodocumentation in a Jeol 5000 scanning electron microscope.

\section{Phenotypic quantification of Drosophila eyes}

To quantify the phenotypical differences between adult eyes in each Drosophila genotype, we use a computational approach (software https://flynotyper.sourceforge. net) that calculates a phenotypic score based on alterations in the arrangement of ommatidia using SEM pictures of the adult fly eye. Briefly, the Flynotyper software detects the total number of ommatidia, the direction and length of six local vectors from the center to each ommatidium to the neighboring one, and the angle formed between each of these six local vectors and provides a phenotypical score for each analyzed picture. A lower phenotypic score indicates a decrease in disorganization of the ommatidial arrangement, which correlates with a decrease in severity of the eye phenotype [35].

\section{Statistical analyses}

For phenotypical quantification of fly eyes, we recorded the phenotypical score of each picture provided by the Flynotyper software. All phenotypical scores associated with one genotype were averaged and analyzed by 
ANOVA Prism 6 (GraphPad). Final images were created using Photoshop CS5 (Adobe Systems). All values in the text and figures represent in a box and whisker graph which represents median, quartiles, and means \pm standard error of the mean.

\section{Results}

Overexpression of $A \beta$ peptides via $A A V$ delivery results in amyloid deposits in the mouse brain

FAD-related $A \beta$ mutant species are prone to accelerate aggregation and increase toxicity compared to $A \beta$ WT [17, 20, 36-41]. We selected specific mutations associated with the aggressive formation of aggregates, such as oligomers or fibrils, both in a test tube and in vivo. Figure 1 illustrates the numerous mutants that were assessed in this study. All BRI2-A $\beta 40$ and A 342 mutant constructs were packaged into the rAAV2/1 viral cassette, expressed in HEK cells, and the truncation and proper secretion of the $A \beta$ peptide to the media was confirmed (Fig. S1). Various levels of $A \beta$ were detected by Western blotting and sandwich ELISA, suggesting differences in half-life and stability of the different mutants. Further, all constructs were packaged into rAAV2/1 and injected into newborn mice as described previously [32, 42, 43].
rAAV-EGFP was used as a control. Each viral construct was delivered into two litters, and brains were extracted at 6 months post-injection (4-6 mice per group). One hemibrain was frozen for biochemical analysis, and the other was fixed and paraffin embedded for immunohistochemistry. We stained the brain sections with a pan-A $\beta$ antibody.

The data shown in Fig. 2a and Table 1 demonstrates robust amyloid deposition in mice injected with rAAVBRI2-A 442 WT, A 342 E22Q, A 342 E22Q/D23N, A 342 $\triangle E 22, A \beta 42$ S26C, and $A \beta 42$ S8A and to a small extent A 342 S8E, 6 months after injection. As shown in Fig. 2b, despite extensive variability, it is clear that mutants $\mathrm{A} \beta 42 \mathrm{E} 22 \mathrm{G}$ and $\mathrm{A} \beta 42 \mathrm{E} 22 \mathrm{Q} / \mathrm{D} 23 \mathrm{~N}$ as well as A $342 \mathrm{WT}$ were detected in both SDS-soluble and the SDSinsoluble, FA-soluble fractions, suggesting an increased prevalence of compact, "cored" plaques, whereas $A \beta 42$ $\triangle E 22, A \beta 42$ S8A, A 342 S8E, and A 342 S26C deposits were more SDS-soluble, corresponding to more diffuse plaques. Interestingly, overexpression of the phosphomimetic A 342 S8E resulted in sparse deposits, with very low levels of both SDS-soluble and FA-soluble A $\beta 42$, whereas non-phospho-mimetic A $\beta 42$ S8A exhibited increased deposits, suggesting that phosphorylation does not play a significant role in $A \beta 42$ deposition.

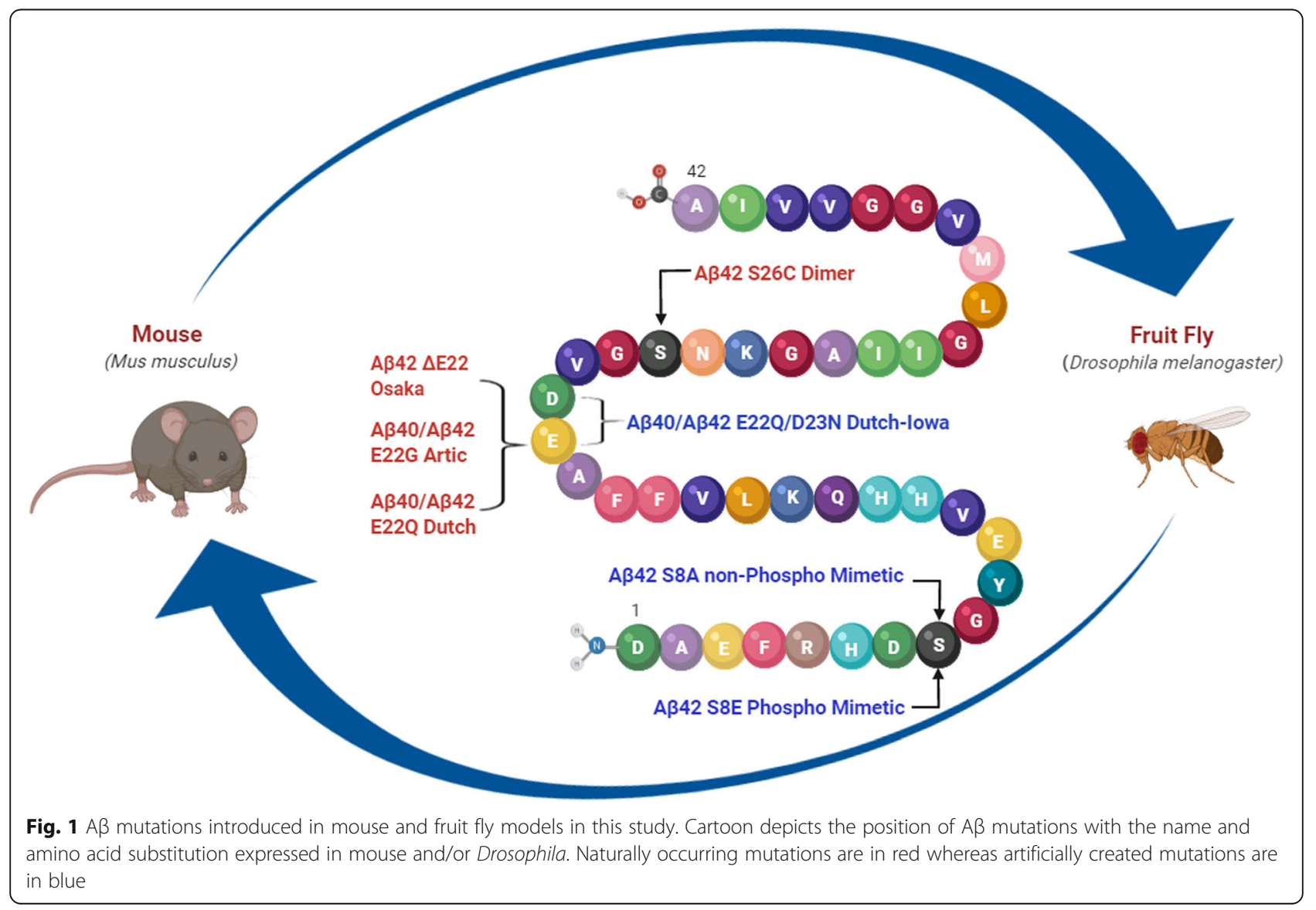




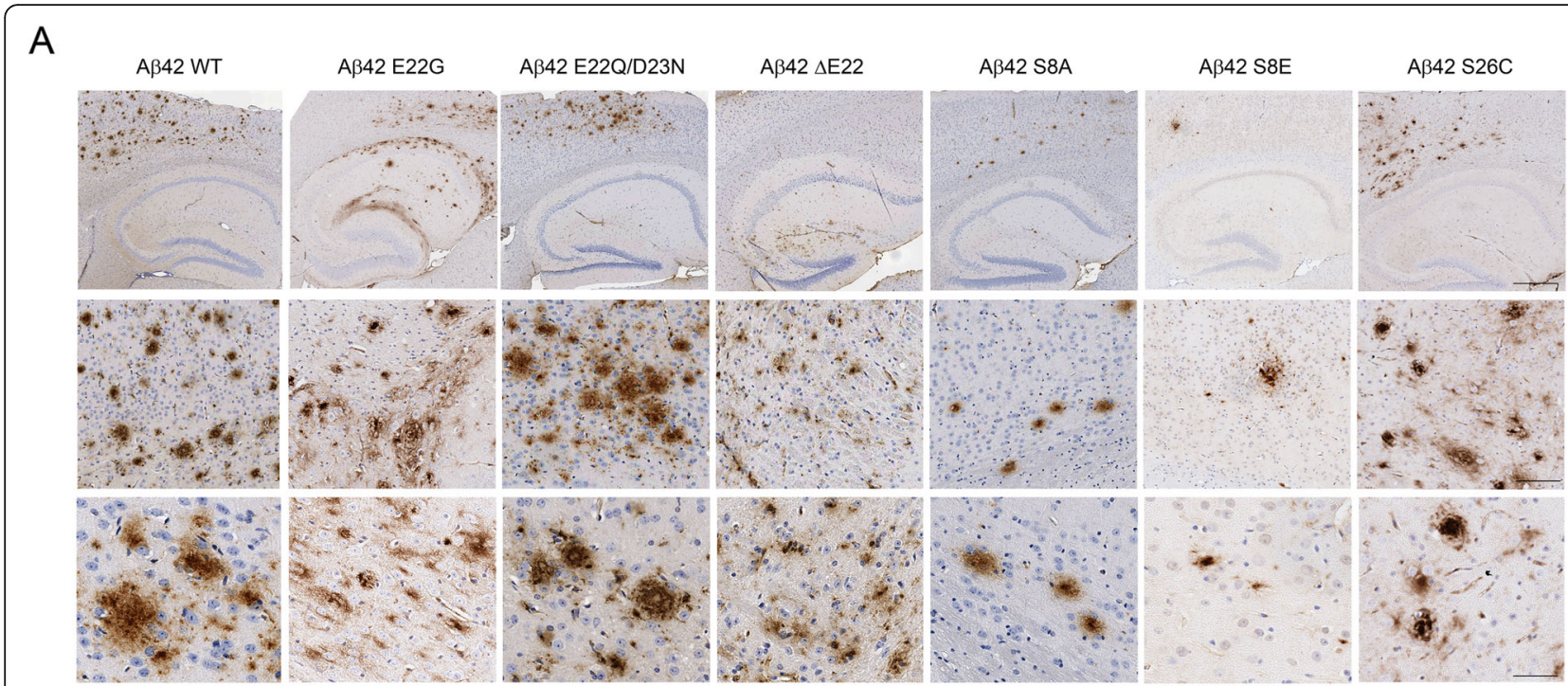

B

$2 \%$ SDS $70 \%$ FA
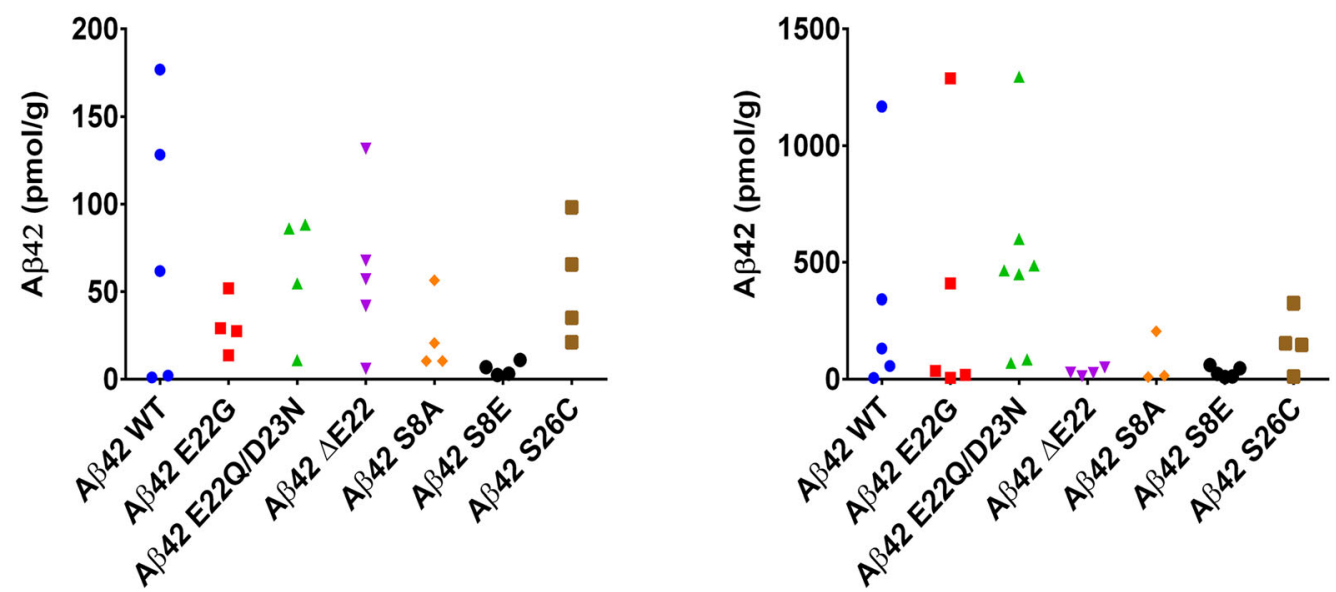

Fig. 2 Brain expression of Aß42 WT and mutants results in unique amyloid deposition. Newborn B6C3F1 pups were bilaterally injected ICV with $4 \mu \mathrm{I}$ rAAV1-BRI-AB42 (10 $13 \mathrm{vg} / \mathrm{ml})(\mathrm{WT}, \mathrm{E} 22 \mathrm{G}, \mathrm{E} 22 \mathrm{Q} / \mathrm{D} 23 \mathrm{~N}, \Delta \mathrm{E} 22, \mathrm{~S} 8 \mathrm{~A}, \mathrm{~S} 8 \mathrm{E}$, or S26C). After 6 months, mice were euthanized, and brains were extracted and processed. a Representative brain sections were stained with pan-A $\beta$ antibody and counterstained with hematoxylin. Scale bar, $60 \mu \mathrm{m}, 200 \mu \mathrm{m}$, $500 \mu \mathrm{m} ; n=4-10$. b The second hemibrain was sequentially extracted in 2\% SDS followed by $70 \% \mathrm{FA}$, and A $\mathrm{B}$ levels were quantified using $A \beta$ sandwich ELISA with C-terminal-specific mAb as capture and pan-A $\beta$ mAb as detection. Each dot represents an individual mouse brain, $n=4-10$

We have previously shown that overexpression of WT A $\beta 40$ resulted in no amyloid pathology [44]. However, when a series of BRI2-A $\beta 40$ mutants were overexpressed in the neonatal brain, we observed that $A \beta 40$ E22G and E22Q/D23N aggregated and accumulated in the brain (Fig. 3a). Interestingly, amyloid deposits of the $A \beta 40$ $\mathrm{E} 22 \mathrm{Q} / \mathrm{D} 23 \mathrm{~N}$ double mutant were detected in both the SDS fraction and FA fraction, whereas A 340 E22G deposits were almost entirely SDS-soluble, suggesting a more diffuse type of amyloid aggregate (Fig. 3b). A $\beta 40$
WT accumulation and aggregation was not detected and neither was $\triangle \mathrm{E} 22$, S8A, S8E, nor S26C (Fig. 3a, b). Notably, accumulation of $A \beta 40$ E22G and E22Q/D23N is the first evidence that $A \beta 40$ overexpression leads to deposition under certain conditions.

\section{Neurotoxic assessment of mutant $A \beta$ peptides in the Drosophila eye}

The Drosophila eye provides an unparalleled and reliable platform to study the contributions of neurotoxic 
Table 1 Summary of pathology occurrence in various WT and mutant $A \beta$-expressing mice

\begin{tabular}{lll}
\hline & A 342 & $\mathbf{A} \beta 40$ \\
\hline WT & $4 / 6$ & $0 / 5$ \\
E22G & $3 / 5$ & $2 / 4$ \\
E22Q/D23N & $5 / 7$ & $4 / 4$ \\
$\Delta$ E22 & $4 / 5$ & $0 / 5$ \\
S8A & $2 / 4$ & $0 / 5$ \\
S26C & $4 / 4$ & $0 / 4$
\end{tabular}

Number of mice with detected pathology per total number of mice injected for each cohort amyloids in vivo. Its photoreceptor neurons are grouped within 800 ommatidia that form an external symmetrical array of hexagonal structures, which are particularly sensitive to $A \beta 42$ insults [45]. Thus, we used this paradigm to compare the neurotoxic properties of wild-type and mutant $A \beta$ peptides upon specific expression in the eye with the GMR-Gal4 driver. We found that flies expressing one copy of the $A \beta 40$ WT or A $\beta 40$ mutants $(A \beta 40$ E22G, S26C, and E22Q) displayed highly organized ommatidia with even distribution of bristles, consistent with the normal phenotype observed in control flies expressing LacZ (compare insets in Fig. 4a). In contrast, and

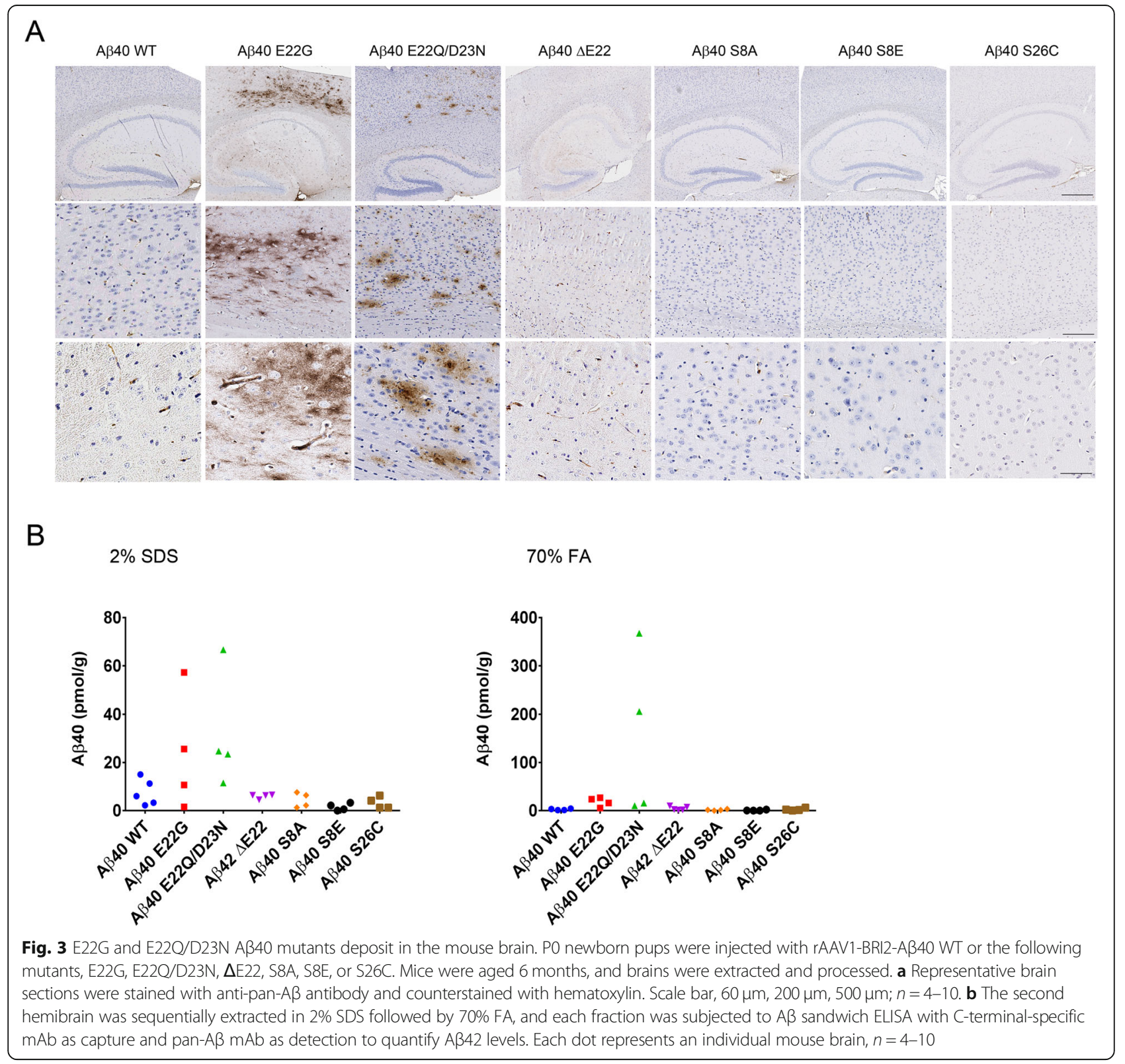


consistent with our previous observations [44], a single copy of the A $\beta 42$ WT induced a more aggressive phenotype characterized by disorganization, ommatidial fusion, and partial lack of bristles (Fig. 4a). Importantly, flies expressing A 342 mutants (A 342 E22G, S26C, and E22Q) exhibited more severe and extensive disorganization with ommatidial perforations and reduction of the eye size (Fig. 4a). These results were confirmed when we performed the quantification of the phenotypical variation of the different $A \beta 40$ as well as $A \beta 42$ lines (Fig. 4b, c).

\section{$A \beta 40$ suppresses $A \beta 42$-induced toxicity}

Next, to examine the potential neuroprotective effect of $A \beta 40$ over $A \beta 42$ toxicity, we generated flies expressing one copy of the transgene encoding each $A \beta 40$ peptide
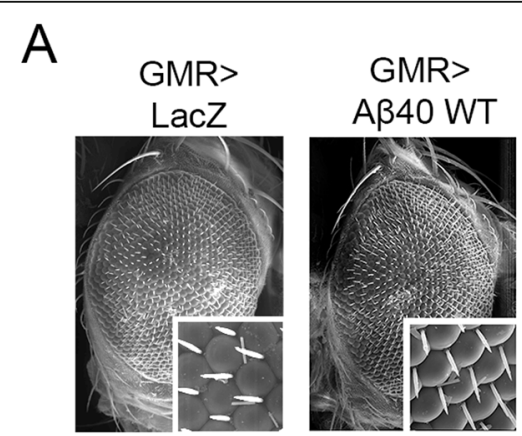

GMR>

GMR>

GMR>

$A \beta 40 E 22 G$

$\mathrm{A} \beta 40 \mathrm{~S} 26 \mathrm{C}$

$A \beta 40 E 22 Q$
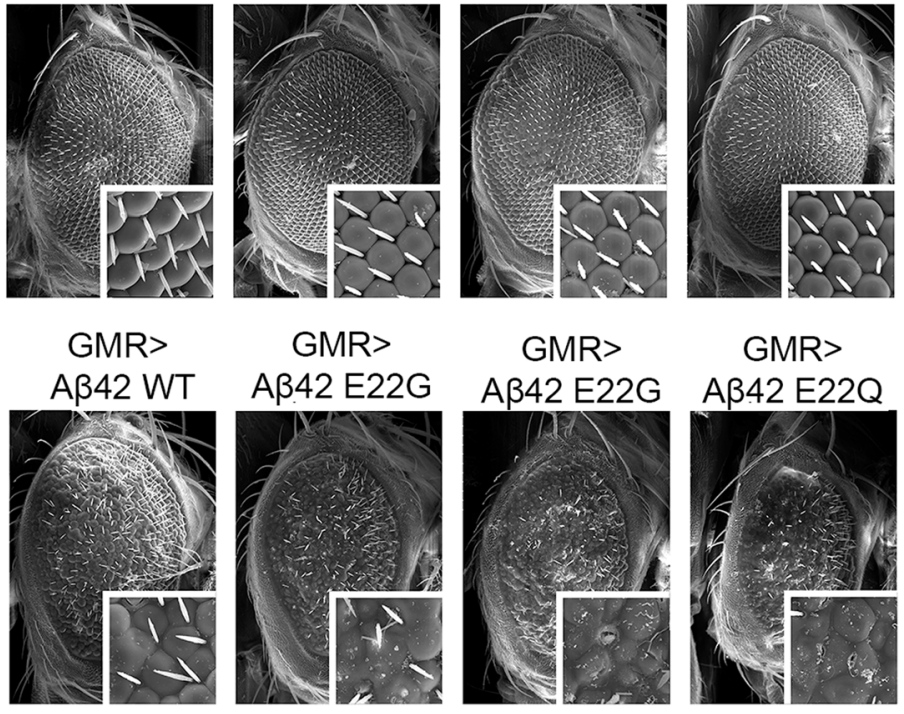

GMR>

GMR>

GMR>
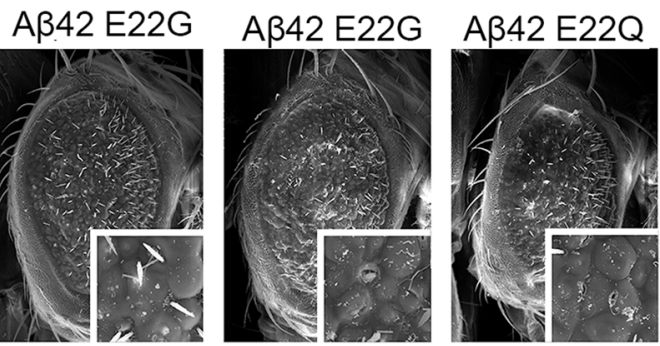

B
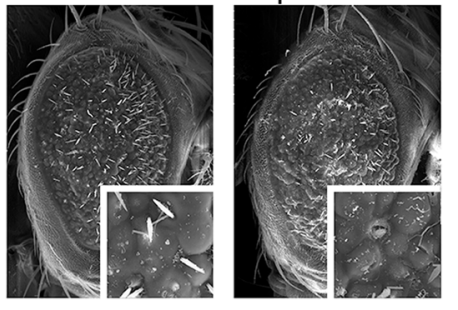

C
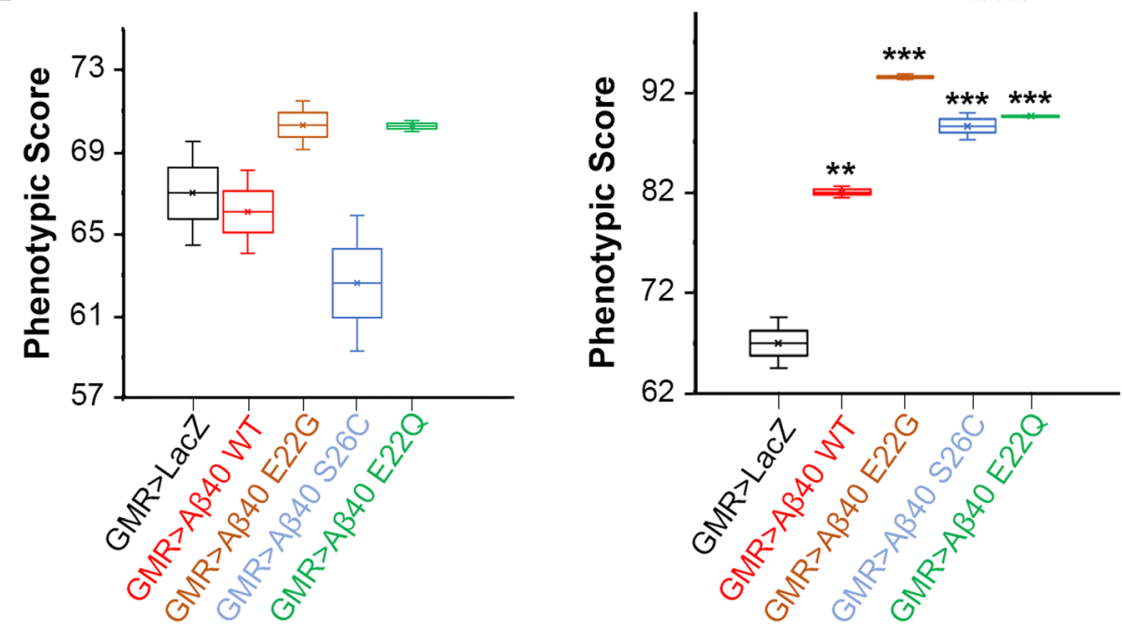

Fig. 4 Phenotypes produced by various A $\beta$ peptides in the Drosophila eye. a Panels show SEM images from fly eyes with the indicated genotypes. Control flies expressing LacZ alone show highly organized eyes with hexagonal lenses. The expression of extracellular A B40 WT, E22G, S26C, and E22Q mutants showed slightly more disorganized ommatidia with no change in size or structure. The expression of extracellular A 42 WT results in small eyes with severe ommatidial disorganization and fusion. A342 E22G, S26C, and E22Q mutants showed higher disorganization with the presence of fusion in ommatidia and sporadic necrotic points. b Box-whisker graph representing the phenotypical scores provided by Flynotyper software of flies expressing A 440 or c A 42 WT and mutant lines. Data shows median, quartiles, and mean percentage of SEM images. A higher phenotypic score indicates an increase in disorganization of the ommatidial arrangement, which correlates with an increase in severity of the eye phenotype. $p$ values obtained from comparing GMR $>$ A 42 WT and mutants to GMR $>$ LacZ. ANOVA, ${ }^{* *} p<0.001,{ }^{* * *} p<0.0001$ 
(A 340 WT, E22G, S26C, and E22Q) over an A 342 WT background. Eye phenotypes in the $A \beta 42$ background co-expressed with $A \beta 40$ showed a slight betterment on phenotype, manifested as a decrease in the number of fused ommatidia and loss of bristles (Fig. 5a). Moreover, we detected mild changes regarding ommatidia disorganization in the anterior part of the eye compared to the control sample (A $442 ; \mathrm{LacZ})$ and a noticeable decrease of necrotic spots (Fig. 5a).

Then, to better assess the effects of these combinations over the general structure of the Drosophila eye, we quantified the phenotypical variation of the different A $\beta 42$ with $A \beta 40$ combinations using the Flynotyper software. In the Flynotyper program, we chose $N=300$ as

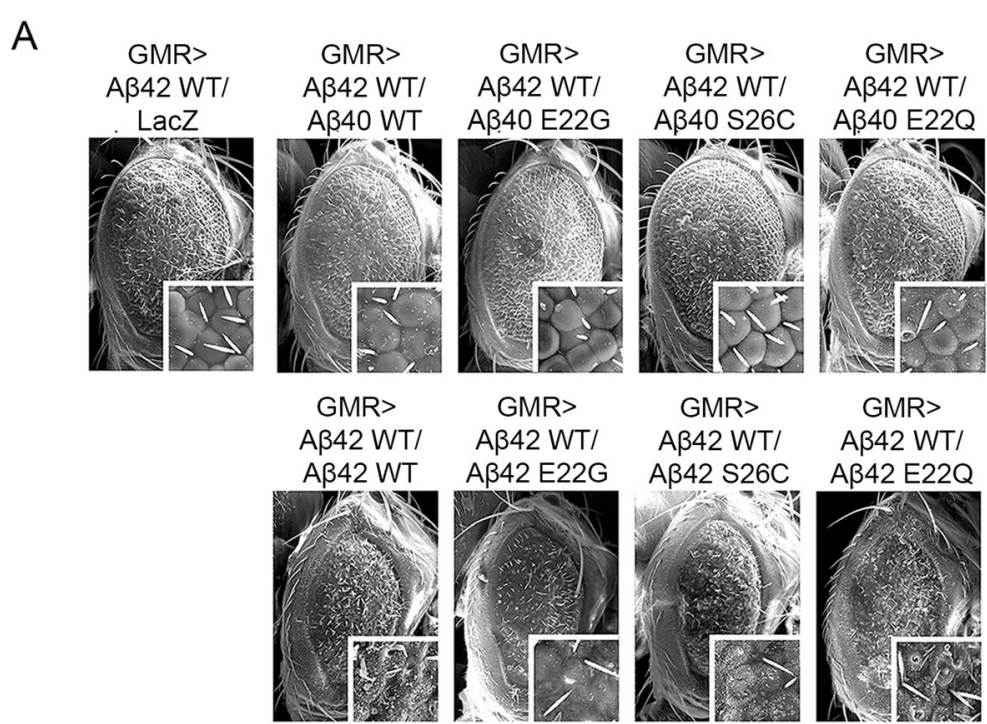

B

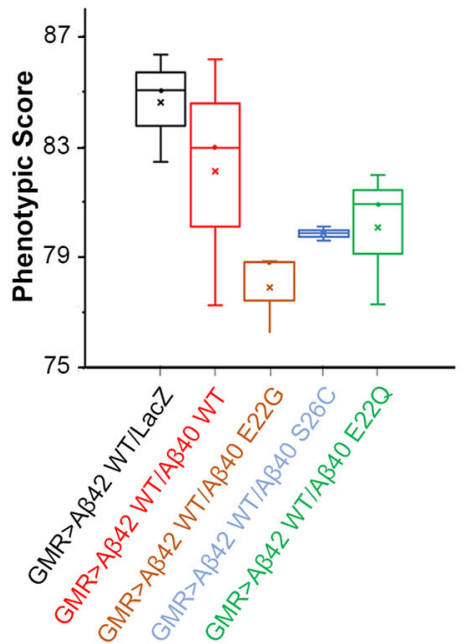

C

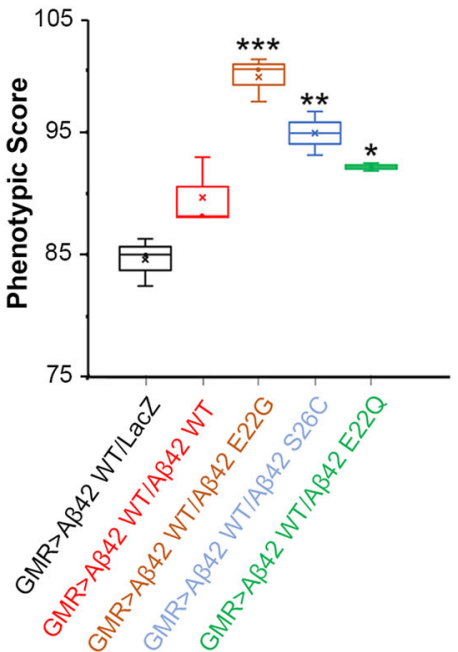

Fig. 5 A 440 mutants are more protective than $A \beta 40$ WT. a Panels show SEM of flies co-expressing $A \beta 42 W T$ and mutant $A \beta 40$ and $A \beta 42$. Interestingly, co-expressing A 42 WT with A 40 WT, A 40 E22G had no effect on the overall eye phenotype, showing similar size and degree of organization in the

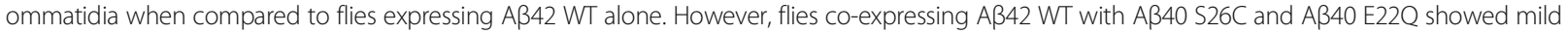
improvement on ommatidia organization at the anterior part of the eye. Flies co-expressing A 442 together with $A \beta 42$ mutants (E22G, S26C, and E22Q) produced a more severe phenotype with small and disorganized eyes, fused ommatidia, and frequent appearance of necrotic spots. $\mathbf{b}$ Box-whisker graph representing the phenotypical scores provided by Flynotyper software of flies co-expressing $A \beta 42 W T$ and $A \beta 40$ with mutations. Data shows median, quartiles, and mean percentage of SEM flies images $(n=3)$. Flies expressing A $342 \mathrm{WT}+$ LacZ (black), A $342 \mathrm{WT}+\mathrm{A} \beta 40 \mathrm{WT}$ (red), A $342 \mathrm{WT}+$ A 40 E22G (brown), A 342 WT + A 40 S26C (blue), and A 342 WT + A 40 E22Q (green) were analyzed. A lower phenotypic score indicates a decrease in disorganization of the ommatidial arrangement, which correlates with a decrease in severity of the eye phenotype. $\mathbf{c}$ Box-whisker graph representing the phenotypical scores provided by Flynotyper software of flies co-expressing $A \beta 42$ WT and $A \beta 42$ with mutations. Data shows median, quartiles, and

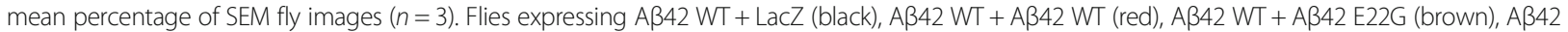
$W T+A \beta 42$ S26C (blue), and A $42 W T+A \beta 42 E 22 Q$ (green) were analyzed. A higher phenotypic score indicates an increase in disorganization of the ommatidial arrangement, which correlates with an increase in severity of the eye phenotype. ANOVA, ${ }^{*} p<0.01,{ }^{* *} p<0.001,{ }^{* * *} p<0.0001$ 
the default number of ommatidia, to allow for a finer phenotypic distinction. While no statistical differences in phenotype manifested, flies expressing $A \beta 40$ mutations (S26C, E22G, and E22Q) showed an improvement in phenotypical score compared to flies co-expressing A 342 with GFP corroborating our initial assessment (Fig. 5b and Table 2).

In addition, we investigated the effect of co-expressing A $\beta 42$ WT flies with a second copy of A $\beta 42$ WT or A $\beta 42$ mutant lines. Surprisingly, while only A $342 / A \beta 42$ E22Q flies showed a markedly exacerbated phenotype characterized by a significant increment in the presence of ommatidial perforations and necrotic spots in the eye, coexpression of A 342 WT, S26C, and E22G showed an elliptical-shaped eye with ommatidial disorganization, perforation, and fusion more characteristic of $A \beta 42 /$ $A \beta 42$ control (Fig. 5a). Interestingly, the quantitative phenotypical analysis confirmed A $\beta 42 / \mathrm{A} \beta 42$ E22G genotype as the more toxic phenotype $(p<0.0001)$ while revealing a significant increase in disorganization of $A \beta 42 /$ A 342 S26C and E22Q when compared to control flies carrying a single copy of A $\beta 42$ (A $\beta 42 / G F P$ ) (Fig. $5 c$ and Table 3).

\section{Discussion}

Although the majority of $\mathrm{AD}$ cases are sporadic, there are several FAD mutations with amino acid substitutions in APP that alter $A \beta$ aggregation rates and result in accelerated disease progression with other pathologies, such as CAA. These mutations have been exploited in mouse models as tools to study $A \beta$ aggregation and to inform therapeutic development. Despite recent reports showing that $A \beta$ can behave like a prion-like strain and FAD mutations inducing unique phenotypes [46], the link between $A \beta$ aggregation and neurodegeneration is unclear. In this study, we overexpressed $A \beta$ mutant peptides in the absence of APP in the brains of neonatal mice and showed predisposition to aggregation of $A \beta 42$ WT and mutants. Further, we examined the effect of exclusively expressed $A \beta$ mutant peptides on the structure of the Drosophila eye. Our results show that although mice mutations in $A \beta 40$ can lead to similar toxic outcome to mutations introduced in $A \beta 42$, that is not the case in the fly model. For instance, the expression of $\mathrm{A} \beta 40$ and $\mathrm{A} \beta 42, \mathrm{E} 22 \mathrm{G}$ and $\mathrm{E} 22 \mathrm{Q} / \mathrm{D} 23 \mathrm{~N}$ resulted in an increased amyloid deposition in mice. However, in flies, while the $A \beta 42$ E22G and E22Q were highly toxic, $A \beta 40$ E22G and E22Q were protective against $A \beta 42$ toxicity. This can be explained by different pathways $A \beta$ peptide goes through in the two models. In the fly, $A \beta$ peptides are fused to the Argos signal peptide to ensure secretion, whereas in the mouse model $A \beta$ accumulation is a result of overexpression of a fusion protein BRI-A $\beta$ under CBA promoter, delivered via AAV. Secretion of $A \beta$ peptide in this case is dependent on furin cleavage. Thus, the choice of model system used to study $A \beta$ aggregation and neurodegeneration is crucial for understanding the link between them.

We employed the BRI2 system to selectively express the A $\beta$ mutations without APP. The BRI2 system utilizes fusion constructs in which the sequence encoding the 23-amino-acid ABri peptide at the carboxyl terminus of the transmembrane protein BRI is replaced with a sequence encoding $A \beta$ [28]. Constitutive processing of the resultant BRI2-A $\beta$ fusion proteins in transfected cells resulted in high-level expression and secretion of the encoded $A \beta$ peptide. AAV2/1 vectors encoding BRI2-A $\beta$ cDNAs were previously used to achieve high-level hippocampal expression and secretion of the specific encoded $A \beta$ peptide in the absence of APP overexpression [29].

Differential levels of expression may be due to variability of transfection efficiency as well as by variability in furin cleavage efficiency. Thus, if a mutation in the $A \beta$ sequence causes aggregation of the fusion protein, it may make the furin cleavage and, as a result, $A \beta$ secretion, less efficient. Also, since SDS-PAGE is performed in reducing conditions, some of the low molecular weight soluble $A \beta$ aggregates may be seen as a monomer on Western blot but might not be detected by ELISA.

Despite these limitations, when overexpressed in the mouse brain, $A \beta$ mutants aggregate and present as unique phenotypes. Thus, A $\beta 42$ WT, E22G, and E22Q/ D23N resulted in more profound SDS-insoluble, FAsoluble aggregates, corresponding to compact plaques, while overexpression of A $342 \Delta \mathrm{E} 22$, S8A, S8E, and S26C resulted in mostly SDS-soluble material, corresponding to diffuse plaques. Indeed, the E22G mutation favored fast $A \beta$ fibrillization and aggregation $[47,48]$. Our findings suggest that the E22G and E22Q/D23N mutations affected the aggregation kinetics most profoundly. These mutations accelerated the overall aggregation by the modulation of the nucleation processes, whereas the elongation process was not significantly affected [49]. This shift in kinetics resulted in amyloid deposition, even with $A \beta 40$, while $A \beta 40$ WT and other $A \beta 40 \mathrm{mu}$ tants did not result in deposition [46]. It is important to note that both familial AD and CAA-related mutations,

Table 2 Phenotypical scores in flies co-expressing $A \beta 42$ with $A \beta 40$ WT and mutants

\begin{tabular}{|c|c|c|c|c|c|}
\hline Phenotypical score & Aß42 WT; LacZ & $A \beta 42 W T ; A \beta 40 W T$ & $A \beta 42 \mathrm{WT} ; A \beta 40$ E22G & $A \beta 42 \mathrm{WT} ; A \beta 40 \mathrm{~S} 26 \mathrm{C}$ & $A \beta 42 W T ; A \beta 40 E 22 Q$ \\
\hline Mean \% $\%$ SD & $84.59 \pm 1.96$ & $82.11 \pm 4.50$ & $77.87 \pm 1.62$ & $79.85 \pm 0.35$ & $80.05 \pm 2.4$ \\
\hline
\end{tabular}


Table 3 Phenotypical scores in flies co-expressing $A \beta 42$ with $A \beta 42$ WT and mutants

\begin{tabular}{|c|c|c|c|c|c|}
\hline nenotypical score & Aß42 WT; LacZ & $A \beta 42 W T ; A \beta 40 W T$ & $A \beta 42 W T ; A \beta 40 E 22 G$ & $A \beta 42 W T ; A \beta 40$ S26C & $A \beta 42 W T ; A \beta 40 E 22 Q$ \\
\hline 5 & $84.59 \pm 1.96$ & $89.71 \pm 1.6$ & $99.47 \pm 1.77$ & $94.90 \pm 1.77$ & $92.17 \pm 0.48$ \\
\hline
\end{tabular}

such as $\mathrm{E} 22 \mathrm{Q}, \mathrm{E} 22 \mathrm{G} / \mathrm{D} 23 \mathrm{~N}, \Delta \mathrm{E} 22$, as well as rationally designed mutations S8A, S8E, and S26C, led to amyloid deposition when overexpressed in the mouse brain.

Another interesting aspect of the FAD mutations within the $A \beta$ sequence is that they lead to remarkable phenotypic diversity in the abundance of CAA [50,51]. In our study, we did not detect CAA following unique BRI2-A $\beta$ overexpression, suggesting that vascular deposits require a diverse mix of $A \beta$ species.

It has been extensively reported that healthy patients present greater deposition of $\mathrm{A} \beta 40$, while most familial and sporadic $A D$ cases have increased $A \beta 42$ deposition or an augmented $A \beta 42$ to $A \beta 40$ ratio. This is believed to be due to $A \beta 42$ rapidly forming more stable aggregates than $A \beta 40$ in unhealthy brains [52-55]. In addition, pathogenic mutations within the sequence are described to significantly increase oligomerization. For instance, both E22Q and E22G aggregate to form protofibrils and fibrils more rapidly than WT A 342 [46]. Our Drosophila results support these findings. As shown in Fig. 4, A 440 WT flies presented highly organized ommatidia with even distribution of bristles similar to the healthy control group. In contrast, a single copy of the $\mathrm{A} \beta 42 \mathrm{WT}$ or mutant peptides (Aß42 E22G, S26C, and E22Q) induced a classic rough eye phenotype characterized by disorganized ommatidial assembly, ommatidial fusions, and loss of interommatidial bristles consistent with a more toxic effect of $A \beta 42$ peptides.

Moreover, our A 342 E22G and E22Q lines showed significant toxicity during development (data not shown), leading to substantial pupal lethality. This coincides with previous studies where A 342 E22G led to significantly high rates of lethality in development as well as detriment in climbing capacity compared to A $\beta 42 \mathrm{WT}$ flies [56]. One explanation resides in the hypothesis that mutations at position 22, including E22Q and E22G, increase neurotoxicity in $\mathrm{A} \beta 42$ by stabilizing a $\mathrm{C}$-terminal core that accelerates aggregation [57].

The results of our study illustrate the differences between $A \beta 40$ and $A \beta 42$, supporting other studies that demonstrated the significance between the structural differences among both peptides [58, 59]. Additionally, it has been suggested that small changes in the $A \beta 42$ to A $\beta 40$ ratio affect aggregation kinetics, the morphology of the resulting amyloid fibrils, and synaptic function both in vitro and in vivo [60]. However, our results also demonstrate that $A \beta 40$ could potentially protect against $A \beta 42$ aggregation.
Although the overall phenotype score of the A $\beta 40 /$ A $\beta 42$ flies compared to A $\beta 42 / G F P$ control group did not reach statistically significant differences. Flies coexpressing $A \beta 40$ on an $A \beta 42$ background, specifically A $\beta 40$ mutants, had a moderately improved ommatidial organization and notable decrease in the number of necrotic spots throughout the adult eye, suggesting a protective effect of $A \beta 40$ peptides against $A \beta 42$. These results were striking. Multiple reports suggest that introduction of mutations in $A \beta 40$ peptides induce an amyloidogenic phenotype similar to A $\beta 42$ [57, 61-63]. More recently, Yoo et al. showed that the heterozygous E22G pathogenic mutation of $A \beta 40$ enhances misfolding of $A \beta$ via cross-seeding from $A \beta 42$ WT fibril that could potentially be responsible for early-onset AD phenotypes [64].

While the exact sequence of events that causes AD remains to be identified, aggregation of the $A \beta$ peptide is a critical step in this process. We believe that, although most cases involve WT A $\beta$, significant insights on the steps of aggregation can be gained by studying the effects of point mutations implicated in early-onset AD.

\section{Limitations}

First, FAD represents a very small fraction of overall $A D$ cases; thus, studying the formation of amyloid pathology on $\mathrm{A} \beta$ mutants does not represent sporadic $\mathrm{AD}$. The lack of direct correlation between amyloid accumulation, $\mathrm{A} \beta$-induced toxicity, and neurodegeneration is a limitation to a single model study, emphasizing the importance of using two or more $A \beta$ overexpression models, such as mice and fruit flies. Second, the somatic brain transgenics AAV delivery technology, utilized in our research, results in substantial variability of amyloid deposition. Future studies focusing on adult injections of AAV-BRI-A $\beta$ under neuronal promoter are advisable. Third, although we expect levels of expression to remain identical between the various mutant lines, we cannot rule out the possibility of different degrees in protein accumulation and toxicity that could be responsible for some of the differences observed between samples; neither we can confirm that $A \beta 42$ degradation ratio and aggregation process is comparable between the fly and mouse model. Recapitulation of the same results in future experiments will strengthen the data.

\section{Conclusions}

In summary, by using complimentary approaches of expressing mutations without APP and in both mice and Drosophila, we demonstrated that although some A $\beta 40$ 
mutants show amyloidogenic properties in the mouse brain, they can be protective against A 342 -induced toxicity in fly eye phenotypes. Since Drosophila are a better model of amyloid-induced toxicity than mice, these results emphasize the importance of utilizing multiple models for screening therapeutic agents.

\section{Supplementary information}

Supplementary information accompanies this paper at https://doi.org/10. 1186/s13195-020-00698-z

Additional file 1 : Figure $\mathbf{S 1}$. $A \beta$ levels in the cell culture media following PAAV transfection. PAAV-BRI2-A 3 constructs were transfected into 293 T cells using Polyethylenimine (PEI). A $\beta$ levels secreted into the culture media were detected by Western blotting (A) with $\mathrm{N}$-terminal specific $82 \mathrm{E} 1$ antibody and by sandwich ELISA (B) using C-terminal A $\beta 40$ or $A \beta 42$ specific antibody for capture and HRP-conjugated pan-A $\beta$ antibody that recognizes $A \beta 1-16$ epitope or $4 \mathrm{G} 8$ (anti $A \beta 17-24$ ) as a detection.

\section{Abbreviations}

AD: Alzheimer's disease; A $\beta$ : Amyloid- $\beta$; CBA: Chicken $\beta$-actin promoter; rAAV: Recombinant adeno-associated virus; CAA: Cerebral amyloid angiopathy; FAD: Familial Alzheimer's disease; GFP: Green fluorescent protein; GMR: Glass multimer reporter

\section{Acknowledgements}

We would like to thank the Center for Translational Research in Neurodegenerative Diseases, McKnight Brain Institute, and Mayo Clinic College of Medicine for continuous support.

\section{Authors' contributions}

L.D.M, B.D.M, J. M, and K.L.D. performed the fly experiments. P.E.C, C.C.D, and K.R.J-W did the molecular cloning. Y. L and M.A.S. performed the animal experiments. B.D.M, Y.L., D.R-L, and T.E.G planned the experiments. B.D.M, L.D.M, and Y. L wrote the manuscript. K.D.D. assisted in making the illustration. B.D.M, L.D.M, Y. L, D.R.-L, and T.E.G edited the manuscript. The authors read and approved the final manuscript.

\section{Funding}

The authors were partially supported by funding from the National Institutes of Health (AG046139, AG047266, AG064914 to T.E. Golde), Stop AD (T.E. Golde), Alzheimer's Association New Investigator grant (YL), and the Ed and Ethel Moore AD Research Program from the Florida Department of Health (DERL).

\section{Availability of data and materials}

All data generated or analyzed during this study are included in this published article [and its supplementary information files].

\section{Ethics approval and consent to participate}

All experiments using mice were carried out according to an Animal Use Protocol approved by the Institutional Animal Care and Use Committee at University of Florida.

\section{Consent for publication}

All authors have approved of the manuscript and agree with its submission.

\section{Competing interests}

The authors declare no conflict of interest.

\section{Author details}

${ }^{1}$ Department of Neurology, McKnight Brain Institute, University of Florida and Norman Fixel Institute for Neurological Diseases, Gainesville, FL, USA. ${ }^{2}$ Center for Translational Research in Neurodegenerative Disease and Department of Neuroscience, Gainesville, FL, USA. ${ }^{3}$ McKnight Brain Institute, College of Medicine, University of Florida, Gainesville, FL, USA. ${ }^{4}$ Department of Neuroscience, Mayo Clinic, Jacksonville, FL, USA.
Received: 23 July 2020 Accepted: 29 September 2020

Published online: 17 October 2020

\section{References}

1. Selkoe DJ. Folding proteins in fatal ways. Nature. 2003;426(6968):900-4.

2. Hardy J, Selkoe DJ. The amyloid hypothesis of Alzheimer's disease: progress and problems on the road to therapeutics. Science. 2002;297(5580):353-6.

3. Wang R, Sweeney D, Gandy SE, Sisodia SS. The profile of soluble amyloid beta protein in cultured cell media. Detection and quantification of amyloid beta protein and variants by immunoprecipitation-mass spectrometry. J Biol Chem. 1996:271(50):31894-902

4. Golde TE, Koo EH, Felsenstein KM, Osborne BA, Miele L. Gamma-Secretase inhibitors and modulators. Biochim Biophys Acta. 2013;1828(12):2898-907.

5. Jung JI, Premraj S, Cruz PE, Ladd TB, Kwak Y, Koo EH, Felsenstein KM, Golde TE, Ran Y. Independent relationship between amyloid precursor protein (APP) dimerization and gamma-secretase processivity. PLoS One. 2014;9(10):e111553.

6. Golde TE, Eckman CB, Younkin SG. Biochemical detection of Abeta isoforms: implications for pathogenesis, diagnosis, and treatment of Alzheimer's disease. Biochim Biophys Acta. 2000;1502(1):172-87.

7. Takami M, Nagashima Y, Sano Y, Ishihara S, Morishima-Kawashima M, Funamoto S, Ihara Y. Gamma-Secretase: successive tripeptide and tetrapeptide release from the transmembrane domain of beta-carboxyl terminal fragment. J Neurosci. 2009;29(41):13042-52.

8. Borchelt DR, Thinakaran G, Eckman CB, Lee MK, Davenport F, Ratovitsky T, Prada CM, Kim G, Seekins S, Yager D, et al. Familial Alzheimer's diseaselinked presenilin 1 variants elevate Abeta1-42/1-40 ratio in vitro and in vivo. Neuron. 1996;17(5):1005-13.

9. Krone MG, Baumketner A, Bernstein SL, Wyttenbach T, Lazo ND, Teplow DB, Bowers MT, Shea JE. Effects of familial Alzheimer's disease mutations on the folding nucleation of the amyloid beta-protein. J Mol Biol. 2008;381(1):221-8.

10. Haass C, Hung AY, Selkoe DJ, Teplow DB. Mutations associated with a locus for familial Alzheimer's disease result in alternative processing of amyloid beta-protein precursor. J Biol Chem. 1994;269(26):17741-8.

11. Kirkitadze MD, Bitan G, Teplow DB. Paradigm shifts in Alzheimer's disease and other neurodegenerative disorders: the emerging role of oligomeric assemblies. J Neurosci Res. 2002;69(5):567-77.

12. Ono K, Condron MM, Teplow DB. Structure-neurotoxicity relationships of amyloid beta-protein oligomers. Proc Natl Acad Sci U S A. 2009;106(35):14745-50.

13. Teplow DB. Structural and kinetic features of amyloid beta-protein fibrillogenesis. Amyloid. 1998;5(2):121-42.

14. Roychaudhuri $R$, Yang M, Hoshi MM, Teplow DB. Amyloid beta-protein assembly and Alzheimer disease. J Biol Chem. 2009;284(8):4749-53.

15. Herzig MC, Winkler DT, Burgermeister P, Pfeifer M, Kohler E, Schmidt SD, Danner S, Abramowski D, Sturchler-Pierrat C, Burki K, et al. Abeta is targeted to the vasculature in a mouse model of hereditary cerebral hemorrhage with amyloidosis. Nat Neurosci. 2004;7(9):954-60.

16. Davis J, Xu F, Deane R, Romanov G, Previti ML, Zeigler K, Zlokovic BV, Van Nostrand WE. Early-onset and robust cerebral microvascular accumulation of amyloid beta-protein in transgenic mice expressing low levels of a vasculotropic Dutch/lowa mutant form of amyloid beta-protein precursor. J Biol Chem. 2004;279(19):20296-306

17. Nilsberth C, Westlind-Danielsson A, Eckman CB, Condron MM, Axelman K, Forsell C, Stenh C, Luthman J, Teplow DB, Younkin SG, et al. The 'Arctic' APP mutation (E693G) causes Alzheimer's disease by enhanced Abeta protofibril formation. Nat Neurosci. 2001;4(9):887-93.

18. Shimada H, Ataka S, Tomiyama T, Takechi H, Mori H, Miki T. Clinical course of patients with familial early-onset Alzheimer's disease potentially lacking senile plaques bearing the E693Delta mutation in amyloid precursor protein. Dement Geriatr Cogn Disord. 2011;32(1):45-54.

19. Inayathullah M, Teplow DB. Structural dynamics of the DeltaE22 (Osaka) familial Alzheimer's disease-linked amyloid beta-protein. Amyloid. 2011;18(3):98-107.

20. O'Nuallain B, Freir DB, Nicoll AJ, Risse E, Ferguson N, Herron CE, Collinge J, Walsh DM. Amyloid beta-protein dimers rapidly form stable synaptotoxic protofibrils. J Neurosci. 2010;30(43):14411-9.

21. O'Malley TT, Oktaviani NA, Zhang D, Lomakin A, O'Nuallain B, Linse S, Benedek GB, Rowan MJ, Mulder FA, Walsh DM. Abeta dimers differ from monomers in structural propensity, aggregation paths and population of synaptotoxic assemblies. Biochem J. 2014;461(3):413-26.

22. Kumar S, Rezaei-Ghaleh N, Terwel D, Thal DR, Richard M, Hoch M, Mc Donald JM, Wullner U, Glebov K, Heneka MT, et al. Extracellular phosphorylation of the 
amyloid beta-peptide promotes formation of toxic aggregates during the pathogenesis of Alzheimer's disease. EMBO J. 2011;30(11):2255-65.

23. Elder GA, Gama Sosa MA, De Gasperi R. Transgenic mouse models of Alzheimer's disease. Mt Sinai J Med. 2010;77(1):69-81.

24. Dawson TM, Golde TE, Lagier-Tourenne C. Animal models of neurodegenerative diseases. Nat Neurosci. 2018;21(10):1370-9.

25. Pickford F, Coomaraswamy J, Jucker M, McGowan E. Modeling familial British dementia in transgenic mice. Brain Pathol. 2006;16(1):80-5.

26. Lewis J, Dickson DW, Lin WL, Chisholm L, Corral A, Jones G, Yen SH, Sahara N, Skipper L, Yager D, et al. Enhanced neurofibrillary degeneration in transgenic mice expressing mutant tau and APP. Science. 2001;293(5534):1487-91.

27. McGowan E, Pickford F, Kim J, Onstead L, Eriksen J, Yu C, Skipper L, Murphy MP, Beard J, Das P, et al. Abeta42 is essential for parenchymal and vascular amyloid deposition in mice. Neuron. 2005;47(2):191-9.

28. Lewis PA, Piper S, Baker M, Onstead L, Murphy MP, Hardy J, Wang R, McGowan E, Golde TE. Expression of BRl-amyloid beta peptide fusion proteins: a novel method for specific high-level expression of amyloid beta peptides. Biochim Biophys Acta. 2001;1537(1):58-62.

29. Lawlor PA, Bland RJ, Das P, Price RW, Holloway V, Smithson L, Dicker BL, During MJ, Young D, Golde TE. Novel rat Alzheimer's disease models based on AAV-mediated gene transfer to selectively increase hippocampal Abeta levels. Mol Neurodegener. 2007;2:11.

30. Wong PC, Cai H, Borchelt DR, Price DL. Genetically engineered mouse models of neurodegenerative diseases. Nat Neurosci. 2002;5(7):633-9.

31. Wong PC, Cai H, Borchelt DR, Price DL. Genetically engineered models relevant to neurodegenerative disorders: their value for understanding disease mechanisms and designing/testing experimental therapeutics. J Mol Neurosci. 2001;17(2):233-57.

32. Chakrabarty P, Rosario A, Cruz P, Siemienski Z, Ceballos-Diaz C, Crosby K, Jansen K, Borchelt DR, Kim JY, Jankowsky JL, et al. Capsid serotype and timing of injection determines AAV transduction in the neonatal mice brain. PLoS One. 2013;8(6):e67680.

33. Moore BD, Chakrabarty P, Levites Y, Kukar TL, Baine AM, Moroni T, Ladd TB, Das P, Dickson DW, Golde TE. Overlapping profiles of Abeta peptides in the Alzheimer's disease and pathological aging brains. Alzheimers Res Ther. 2012;4(3):18.

34. Pfeiffer BD, Ngo TT, Hibbard KL, Murphy C, Jenett A, Truman JW, Rubin GM. Refinement of tools for targeted gene expression in Drosophila. Genetics. 2010;186(2):735-55.

35. Iyer J, Wang Q, Le T, Pizzo L, Gronke S, Ambegaokar SS, Imai Y, Srivastava A, Troisi BL, Mardon G, et al. Quantitative assessment of eye phenotypes for functional genetic studies using Drosophila melanogaster. G3 (Bethesda). 2016;6(5):1427-37.

36. Kamino K, Orr HT, Payami H, Wijsman EM, Alonso ME, Pulst SM, Anderson L, O'Dahl S, Nemens E, White JA, et al. Linkage and mutational analysis of familial Alzheimer disease kindreds for the APP gene region. Am J Hum Genet. 1992;51(5):998-1014.

37. Levy E, Carman MD, Fernandez-Madrid IJ, Power MD, Lieberburg I, van Duinen SG, Bots GT, Luyendijk W, Frangione B. Mutation of the Alzheimer's disease amyloid gene in hereditary cerebral hemorrhage, Dutch type. Science. 1990:248(4959):1124-6.

38. Van Broeckhoven C, Haan J, Bakker E, Hardy JA, Van Hul W, Wehnert A, VegterVan der Vlis M, Roos RA. Amyloid beta protein precursor gene and hereditary cerebral hemorrhage with amyloidosis (Dutch). Science. 1990;248(4959):1120-2.

39. Fernandez-Madrid I, Levy E, Marder K, Frangione B. Codon 618 variant of Alzheimer amyloid gene associated with inherited cerebral hemorrhage. Ann Neurol. 1991:30(5):730-3.

40. Tomiyama T, Nagata T, Shimada H, Teraoka R, Fukushima A, Kanemitsu H, Takuma $H$, Kuwano R, Imagawa M, Ataka S, et al. A new amyloid beta variant favoring oligomerization in Alzheimer's-type dementia. Ann Neurol. 2008;63(3):377-87.

41. Grabowski TJ, Cho HS, Vonsattel JP, Rebeck GW, Greenberg SM. Novel amyloid precursor protein mutation in an lowa family with dementia and severe cerebral amyloid angiopathy. Ann Neurol. 2001:49(6):697-705.

42. Kim JY, Grunke SD, Levites Y, Golde TE, Jankowsky JL. Intracerebroventricular viral injection of the neonatal mouse brain for persistent and widespread neuronal transduction. J Vis Exp. 2014:91:51863.

43. Kim JY, Ash RT, Ceballos-Diaz C, Levites Y, Golde TE, Smirnakis SM, Jankowsky JL. Viral transduction of the neonatal brain delivers controllable genetic mosaicism for visualising and manipulating neuronal circuits in vivo. Eur J Neurosci. 2013;37(8):1203-20.

44. Moore BD, Martin J, de Mena L, Sanchez J, Cruz PE, Ceballos-Diaz C, Ladd TB, Ran Y, Levites Y, Kukar TL, et al. Short Abeta peptides attenuate Abeta42 toxicity in vivo. J Exp Med. 2018;215(1):283-301.
45. Casas-Tinto S, Zhang Y, Sanchez-Garcia J, Gomez-Velazquez M, Rincon-Limas $D E$, Fernandez-Funez $P$. The ER stress factor XBP1s prevents amyloid-beta neurotoxicity. Hum Mol Genet. 2011;20(11):2144-60.

46. Hatami A, Monjazeb S, Milton S, Glabe CG. Familial Alzheimer's disease mutations within the amyloid precursor protein alter the aggregation and conformation of the amyloid-beta peptide. J Biol Chem. 2017;292(8):3172-85.

47. Sahlin C, Lord A, Magnusson K, Englund H, Almeida CG, Greengard P, Nyberg F, Gouras GK, Lannfelt L, Nilsson LN. The Arctic Alzheimer mutation favors intracellular amyloid-beta production by making amyloid precursor protein less available to alpha-secretase. J Neurochem. 2007;101(3):854-62.

48. Johansson AS, Berglind-Dehlin F, Karlsson G, Edwards K, Gellerfors P, Lannfelt L. Physiochemical characterization of the Alzheimer's disease-related peptides A beta 1-42Arctic and A beta 1-42wt. FEBS J. 2006;273(12):2618-30.

49. Yang X, Meisl G, Frohm B, Thulin E, Knowles TPJ, Linse S. On the role of sidechain size and charge in the aggregation of Abeta42 with familial mutations. Proc Natl Acad Sci U S A. 2018;115(26):E5849-58.

50. Weggen S, Beher D. Molecular consequences of amyloid precursor protein and presenilin mutations causing autosomal-dominant Alzheimer's disease. Alzheimers Res Ther. 2012;4(2):9.

51. Biffi A, Greenberg SM. Cerebral amyloid angiopathy: a systematic review. J Clin Neurol. 2011;7(1):1-9.

52. Bernstein SL, Dupuis NF, Lazo ND, Wyttenbach T, Condron MM, Bitan G Teplow DB, Shea JE, Ruotolo BT, Robinson CV, et al. Amyloid-beta protein oligomerization and the importance of tetramers and dodecamers in the aetiology of Alzheimer's disease. Nat Chem. 2009; 1(4):326-31.

53. Sanchez L, Madurga S, Pukala T, Vilaseca M, Lopez-Iglesias C, Robinson CV, Giralt E, Carulla N. Abeta40 and Abeta42 amyloid fibrils exhibit distinct molecular recycling properties. J Am Chem Soc. 2011;133(17):6505-8.

54. Mann DM, Iwatsubo T, Cairns NJ, Lantos PL, Nochlin D, Sumi SM, Bird TD, Poorkaj P, Hardy J, Hutton M, et al. Amyloid beta protein (Abeta) deposition in chromosome 14-linked Alzheimer's disease: predominance of Abeta42(43). Ann Neurol. 1996;40(2):149-56.

55. Qiu T, Liu Q, Chen YX, Zhao YF, Li YM. Abeta42 and Abeta40: similarities and differences. J Pept Sci. 2015;21 (7):522-9.

56. lijima K, Chiang HC, Hearn SA, Hakker I, Gatt A, Shenton C, Granger L, Leung A, lijima-Ando K, Zhong Y. Abeta42 mutants with different aggregation profiles induce distinct pathologies in Drosophila. PLoS One. 2008;3(2):e1703.

57. Murakami K, Irie K, Ohigashi H, Hara H, Nagao M, Shimizu T, Shirasawa T. Formation and stabilization model of the 42-mer Abeta radical: implications for the long-lasting oxidative stress in Alzheimer's disease. J Am Chem Soc. 2005:127(43):15168-74.

58. Pauwels K, Williams TL, Morris KL, Jonckheere W, Vandersteen A, Kelly G, Schymkowitz J, Rousseau F, Pastore A, Serpell LC, et al. Structural basis for increased toxicity of pathological abeta42:abeta40 ratios in Alzheimer disease. J Biol Chem. 2012;287(8):5650-60.

59. Bate C, Williams A. Amyloid-beta (1-40) inhibits amyloid-beta (1-42) induced activation of cytoplasmic phospholipase A2 and synapse degeneration. J Alzheimers Dis. 2010;21(3):985-93.

60. Kuperstein I, Broersen K, Benilova I, Rozenski J, Jonckheere W, Debulpaep M, Vandersteen A, Segers-Nolten I, Van Der Werf K, Subramaniam $V$, et al. Neurotoxicity of Alzheimer's disease Abeta peptides is induced by small changes in the Abeta42 to Abeta40 ratio. EMBO J. 2010;29(19):3408-20.

61. Lam AR, Teplow DB, Stanley HE, Urbanc B. Effects of the Arctic (E22-->G) mutation on amyloid beta-protein folding: discrete molecular dynamics study. J Am Chem Soc. 2008;130(51):17413-22.

62. Shahnawaz M, Sharoar MG, Shin SY, Park IS. Wild-type, Flemish, and Dutch amyloid-beta exhibit different cytotoxicities depending on Abeta40 to Abeta42 interaction time and concentration ratio. J Pept Sci. 2013;19(9):545-53.

63. Ju Y, Asahi T, Sawamura N. Arctic mutant Abeta40 aggregates on alpha7 nicotinic acetylcholine receptors and inhibits their functions. J Neurochem. 2014;131(5):667-74.

64. Yoo BK, Xiao Y, McElheny D, Ishii Y. E22G pathogenic mutation of beta-amyloid (Abeta) enhances misfolding of Abeta40 by unexpected prion-like cross talk between Abeta42 and Abeta40. J Am Chem Soc. 2018;140(8):2781-4.

\section{Publisher's Note}

Springer Nature remains neutral with regard to jurisdictional claims in published maps and institutional affiliations. 